ABS와 PS 混合 폐플라스틱 材質分利를 위한 摩擦荷電型靜電選別 技術開發

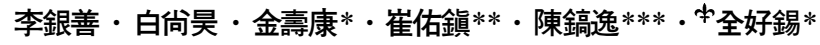 \\ 韓國科學技術聯合大學院大學校, *韓國地質資源研究院, **水原大學校, ***江原地域事業評價院
}

\title{
Development of Triboelectrostatic Separation Technique for Material Separation of ABS and PS Mixed Plastic Waste
}

\author{
Eun-Seon Lee, Sang-Ho Baek, Su-Kang Kim*, Woo-Zin Choi**, \\ Ho-Ill Chin*** and *Ho-Seok Jeon* \\ UST, *KIGAM, **Suwon University, ***Gangwon Regional Evalution Agency
}

\section{요 약}

다양한 분야에 사용되고 있는 플라스틱은 최근 환경문제가 대두되면서 재활용 이슈가 부각되고 있다. 본 연구에서는 마찰하전형 정전선별을 적용하여 $\mathrm{ABS}$ (Acrylonitrile Butadiene Styrene)와 PS(Polystyrene)의 혼합된 폐플라스틱으로부터 ABS를 회수하기 위한 재질분리 연구를 수행하였다. 하전물질의 재질선정을 위한 하전특성연구결과, $\mathrm{ABS}$ 재질이 대상시료인 $\mathrm{ABS}$ 와 $\mathrm{PS}$ 의 혼합 폐플라스 틱의 재질분리에 효과적인 하전재질로 확인되었다. 선정된 하전물질을 적용하여 마찰하전형정전선별을 수행한 결과, 공급전압세기 $20 \mathrm{kV}$, 분리대위치 양극방향 $2 \mathrm{~cm}$ 그리고 상대습도 $30 \%$ 에서 $\mathrm{ABS}$ 의 품위와 회수율이 각각 $99.5 \%$ 와 $92.5 \%$ 인 결과를 얻어, $\mathrm{ABS}$ 와 PS의 혼합 플라스틱의 재활용을 위한 재질분리 기술을 확립하였다.

주제어 : 마찰하전형정전선별, 하전물질, 재질분리, 재활용, 폐플라스틱

\begin{abstract}
Due to the environmental problem caused by plastics largely used in various fields, the importance of recycling is being emphasized. A research on material separation of ABS and PS mixed plastic waste, using a triboelectrostatic separator, was carried out for recovery the ABS. As a results of research on charging characteristic for choosing charging material, it was confirmed that ABS was optimum charging material for a tribo-charger in the material separation of ABS and PS. In the material separation using ABS charger, ABS grade of $99.5 \%$ and recovery of $92.5 \%$ were achieved at $20 \mathrm{kV}$, splitter position $+2 \mathrm{~cm}$ from the center and $30 \%$ relative humidity. Therefore, material separation technique for recycling ABS and PS mixed plastic waste was established.
\end{abstract}

Key words : Triboelectrostatic separation, Charging material, Material separation, Recycling, Waste plastic

\footnotetext{
* Received : August 8, 2013 - Revised : August 30, $2013 \cdot$ Accepted : October 2, 2013

*Corresponding Author : Ho Seok Jeon (E-mail : hsjeon@kigam.re.kr)

Mineral Resources Research Division, Korea Institute of Geoscience \& Mineral Resources, 124 Gwahang-no, Yuseong-gu, Daejeon, 305-350 Korea

Tel : +82-42-868-3582/ Fax : +82-42-868-3637

(C) The Korean Institute of Resources Recycling. All rights reserved. This is an open-access article distributed under the terms of the Creative Commons Attribution Non-Commercial License (http://creativecommons.org/licenses/by-nc/3.0/), which permits unrestricted non-commercial use, distribution and reproduction in any medium, provided the original work is properly cited.
} 


\section{1. 서 론}

플라스틱은 나무 금속, 기타물질들을 대체 가능하고, 가볍고 단단하며 가공이 쉬울 뿐만 아니라 내식성, 절 연성 등 화학적 물성 또한 우수하여 생활 및 산업 전 반에 다양하게 사용되고 있다. 최근 엔지니어링 플라스 틱, 기능성 고분자로 표현되는 각종 특수 플라스틱이 등 장하면서 오히려 ‘제2의 플라스틱 혁명'이 일어나 플라스 틱의 사용범위와 사용량이 지속적으로 확대되고 있다 ${ }^{1-3)}$.

우리나라는 석유화학공업의 발달로 미국, 일본, 독일 에 이어 세계 4 위의 플라스틱 생산국이며, 국민 1 인당 사용량도 세계 8 위 수준으로 국민 1 인당 연간 약 $100 \mathrm{~kg}$ 정도의 플라스틱을 소모하고 있다. 그리고 여러 가지 기능적 우수성과 저가라는 경제성의 특징으로 인 하여 사용량이 증가하고 있으며, 이에 따른 폐플라스틱 의 발생양도 증가하고 있다 ${ }^{3)}$ 플라스틱 사용량 증가에 따른 폐플라스틱의 양도 2003년 3,548천 톤, 2005년 3,968천 톤, 2007년 4,254천 톤으로 그 양이 계속 증 가하고 있는 반면 2007년 기준 폐플라스틱의 재활용률 은 약 $39 \%$ 이며 절반 이상의 양이 매립 또는 소각되고 있다 ${ }^{4}$.

고체 산업폐기물은 소각 및 매립하여 감용화하는 것 이 일반적이나, 폐플라스틱의 소각과 매립은 경제적인 손실뿐만 아니라 환경오염의 거시적인 원인이 되고 있 다. 폐플라스틱의 소각에 의한 처리는 일부 열에너지를 이용할 수 있지만 많은 경제적인 손실을 초래하고, 염 화수소에 의한 소각로의 부식과 다이옥신 등 각종 유독 성 가스를 방출하여 환경문제를 유발할 수 있다. 또한 폐플라스틱의 매립은 매립 부지의 확보문제뿐만 아니라 유해성분이 용출될 수 있으며, 단위무게에 비해 부피가 커 매립효율을 저하시키고, 물리·화학적으로 안정되어 있는 난분해성이라 매립지의 조기 안정화와 훍속에 반 영구적으로 잔존하는 문제가 발생한다. 따라서 정부에 서는 $\operatorname{EPR}($ Expended Product Responsibility)제도를 2003년 1월부터 시행하고 있으며, 향후 폐플라스틱의 소각과 매립을 법으로 규제할 계획에 있어 플라스틱 산 업 및 환경보호를 위해서는 재활용 기술개발이 시급한 실정이다 ${ }^{5}$

플라스틱은 다른 물질에 비해 쉽게 분해 및 변질이 이루어지지 않아, 효율적인 선별 기술만 개발된다면 재 활용이 가장 용이한 물질 중의 하나이다. 이러한 폐플 라스틱을 재활용할 수 있는 기술로는 에너지 재활용, 화 학적 재활용 그리고 물질 재활용의 방법이 있으며, 이
중 플라스틱의 값싼 특성을 고려할 때 물질 재활용이 가장 효율적인 방법으로 평가받고 있다. 그러나 어느 방 법이든 다른 종류의 플라스틱이 혼재되어 있으면 물성 이 크게 저하되기 때문에 플라스틱의 재질분리 기술은 재활용에 있어서 가장 중요하다6). 현재 플라스틱 재활 용은 대부분 수선에 의해 처리되고 있으나, 각 분야별 폐플라스틱 재질분리 기술의 연구가 활발히 진행되어 큰 발전이 이루어지고 있다 ${ }^{7-8)}$.

폐플라스틱을 재자원화 할 수 있는 물리적 선별법은 정전선별, 건·습식 비중선별, 부유선별, 색선별 그리고 분광법 등이 있다 ${ }^{1)}$. 본 연구에서는 전도성물질과 비전 도성 물질에 관계없이 모든 재질의 분리가 가능한 마찰 하전형정전선별법을 적용하여 $\mathrm{ABS}$ (Acrylonitrile Butadiene Styrene)와 PS(Polystyrene)의 혼합 폐플라스틱 재질분리 연구를 수행하였다. 또한 수요량이 높고 고가 의 $\mathrm{ABS}$ 를 회수하는데 주안점을 두어 $\mathrm{ABS}$ 의 회수율과 품위에서 각각 $90 \%$ 와 $99 \%$ 이상의 효율을 보이는 선별 기술을 개발하여 혼합 폐플라스틱의 재활용을 높일 수 있는 재질분리 기술을 확립하였다.

\section{2. 이론적 배경}

마찰하전형 정전선별법은 서로 다른 입자간 또는 입 자와 하전장치간의 접촉을 통해 다른 극성으로 대전시 켜 이를 정전기적으로 분리해 내는 방식이다. Fig. 1은 입자의 마찰대전과정을 나타낸 것으로, (a)는 입자와 하 전장치 표면과의 접촉에 의한 대전을, (b)는 입자와 입 자간의 접촉에 의한 대전현상을 나타내고 있다. 그림에 서와 같이 서로 다른 입자 혹은 하전장치 표면에 충 돌 - 마찰하게 되면 일함수 값(work function)의 차이에 의해 두 물질의 fermi-levelo이 같아지는 방향으로 전자 의 이동이 있게 된다. 접촉 후 입자가 다시 표면에서 분리되면 전자의 과잉 또는 부족현상이 생겨 입자는 negative(-) 혹은 positive(+)로 대전하게 된다. 이렇게

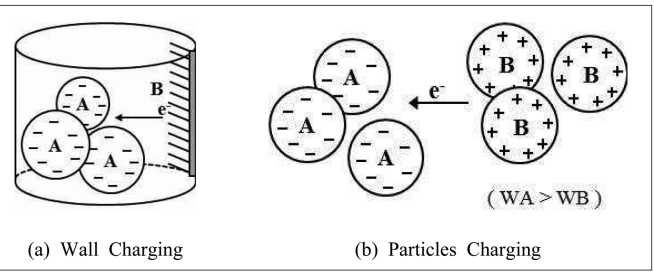

Fig. 1. A charging principle of triboelectrostatic separation. 
서로 반대 극성으로 하전된 혼합 입자들을 높은 전압이 흐르는 전기장 내로 통과시키면 positive로 하전된 입자 는 negative 전극으로 이동하게 되고, 이와 반대로 negative로 하전된 입자는 positive 전극으로 이동되어 분리가 이루어진다 ${ }^{9-11)}$.

\section{3. 시료 및 실험방법}

본 연구에 사용된 시료는 (주세종에서 입수한 폐가전 제품의 플라스틱으로 야적 - 방치되거나 소각 및 매립 처리 되고 있는 $\mathrm{ABS}$ 와 $\mathrm{PS}$ 재질의 폐플라스틱이다. $\mathrm{ABS}$ 와 PS는 6대 범용 플라스틱으로, 2012년 기준 생산 량과 수요량은 $\mathrm{ABS}$ 의 경우 각각 약 145 만 톤, 33 만 톤, $\mathrm{PS}$ 의 경우 각각 약 64 만 톤, 20 만 톤이며, $\mathrm{ABS}$ 가 $\mathrm{PS}$ 에 비해 생산량 약 2.3배, 수요량 약 1.6 배정도 높다. ${ }^{12)}$ 또한 $\mathrm{ABS}$ 와 PS는 기타합성수지에 비해 약 300-500 USD/ton 정도 비싸며, 2012년 기준 $\mathrm{ABS}$ 가 $1,891 \mathrm{USD} / \mathrm{ton}, \mathrm{PS}$ 는 $1,686 \mathrm{USD} / \mathrm{ton}$ 으로 $\mathrm{ABS}$ 의 가격이 PS에 비해 $200 \mathrm{USD} /$ ton정도 비싸다. ${ }^{13)} \mathrm{ABS}$ 와 $\mathrm{PS}$ 는 각각 성형성, 내충격 성, 내약품성, 내열성, 기계적 강도와 전기절연성, 고수 지강도, 열안정성, 접착성, 도장성 등이 우수하여 사무 기기, 자동차부품, 전자기기부품 등에 사용된다. 이중 $\mathrm{ABS}$ 의 경우에는 자동차부품, 전자기기부품 등에 널리 사용되고 있으며 국내뿐만 아니라 전 세계적으로 생산 량이 급격히 증가하고 있다. ${ }^{4)}$

Fig. 2는 폐플라스틱 ABS와 PS의 대전서열 및 하전 특성 연구를 위해 사용한 수직왕복형 하전장치와 재질 별 하전통(PTFE(polytetrafluoroethylene), PVC(polyvinyl chloride), PP, HDPE, PET, HIPS, ABS, POM,

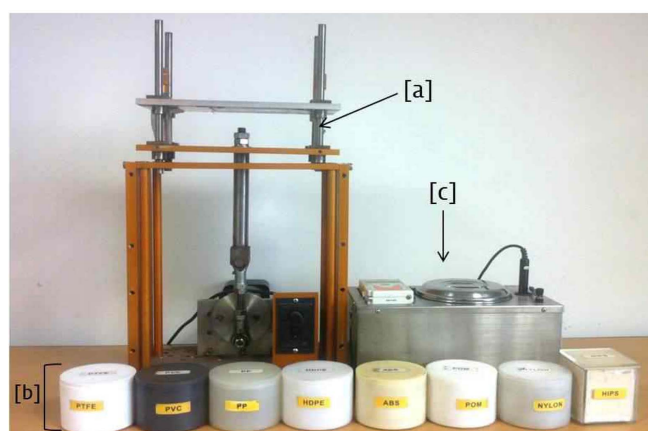

Fig. 2. A Vertical-reciprocation charger set and peripheral measurement $(\mathrm{a}:$ vertical-reciprocation, $\mathrm{b}:$ charging bottles, c : Faraday cage).

Nylon)을 나타낸 것이다. 하전물질 선정을 위하여, 먼저 대상 시료인 $\mathrm{ABS}$ 와 $\mathrm{PS}$ 는 각각 cutting mill에 의해 $6 \mathrm{~mm}$ 이하로 파쇄하고 체 $(1 \mathrm{~mm})$ 에 의해 $1 \sim 6 \mathrm{~mm}$ 크기 로 입도조절 하였다. 입도 조절된 시료는 다양한 하전 통에 투입하여 수직왕복형 하전장치에 의해 마찰 - 충 돌시킨 후, Fig. 2의(c)에 제시한 Faraday cage로 하전 극성 및 하전량을 측정하였다. 그리고 이를 기초로 하 여 $\mathrm{ABS}$ 와 $\mathrm{PS}$ 의 혼합 폐플라스틱의 재질분리를 위한 마찰하전형 정전선별의 하전물질을 선정하였다.

Fig. 3은 본 실험의 공정도를 나타낸 것으로, 대상 시료를 1 6 mm의 크기로 파쇄 및 입도조절한 후, 무게 비 $1: 1$ 로 혼합하였다. 입도조절된 시료는 $\mathrm{ABS}$ 재질의 하전통에 투입하여 수직왕복형 하전장치에 의해 마찰충돌에 의해 하전시킨 후, 서로 다른 극으로 하전된 입 자를 고전압이 흐르는 전기장에 이동시켜 분리하였다. 또한 전극의 전압세기, 분리대의 위치, 습도 등의 실험

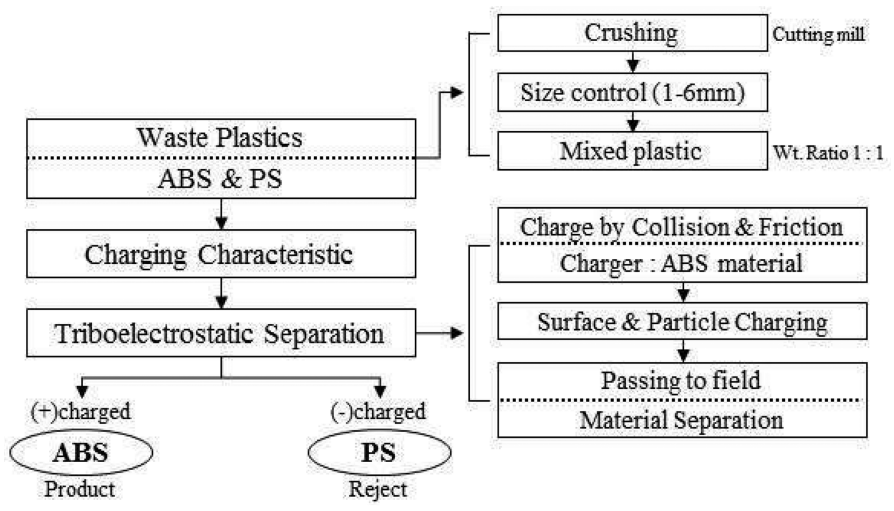

Fig. 3. Flowchart of material separation test by using triboelectrostatic separator. 
조건을 변화하면서 최적 선별조건 및 분리효율을 확인 하였다.

\section{4. 실험결과 및 고찰}

\section{1. 하전특성}

$\mathrm{ABS}$ 와 PS 혼합 폐플라스틱의 재질분리를 위하여, 시 료를 각각 반대 극성으로 하전 시킬 수 있는 하전물질 을 선정하기 위한 하전특성 연구를 수행하였다. 서로 다 른 일함수 값과 대전서열을 가진 재질별 하전통에 시료 를 각각 단일 상태로 투입하고 수직왕복형 하전장치를 이용하여 하전 시킨 후, Faraday cage를 이용하여 하전 극성과 하전량을 측정하였다. 실험변수인 상대습도와 온 도는 각각 $40 \%$ 와 $15^{\circ} \mathrm{C}$ 로, 회전속도와 체류시간은 $270 \mathrm{rpm}$ 과 2분으로 조절하여 실험을 수행하였다.

Fig. 4는 하전특성 실험결과를 나타낸 것이다. 대상 시료인 $\mathrm{ABS}$ 와 $\mathrm{PS}$ 의 일함수 값이 하전물질 $\mathrm{PTFE,}$ PVC, PP, HDPE보다 낮아 모두 양으로, POM, Nylon 보다 높아 모두 음으로 하전이 이루어졌다. 반면 PET, $\mathrm{HIPS}$ 그리고 $\mathrm{ABS}$ 의 경우, $\mathrm{ABS}$ 와 $\mathrm{PS}$ 가 반대 극성으 로 하전이 이루어짐을 알 수 있다. 이때 대상시료와 동 일 재질인 $\mathrm{ABS}$ 와 $\mathrm{PS}$ 가 대상시료를 반대로 하전시키는 이유는, 동일한 재질이라 하더라도 플라스틱의 내부구 조, 첨가제 등의 화학적 성분차이로 인해 일함수 값이 달라지기 때문이다. 따라서 ABS, HIPS 그리고 PET가 대상시료 $\mathrm{ABS}$ 와 $\mathrm{PS}$ 사이에 일함수 값이 존재하여 각

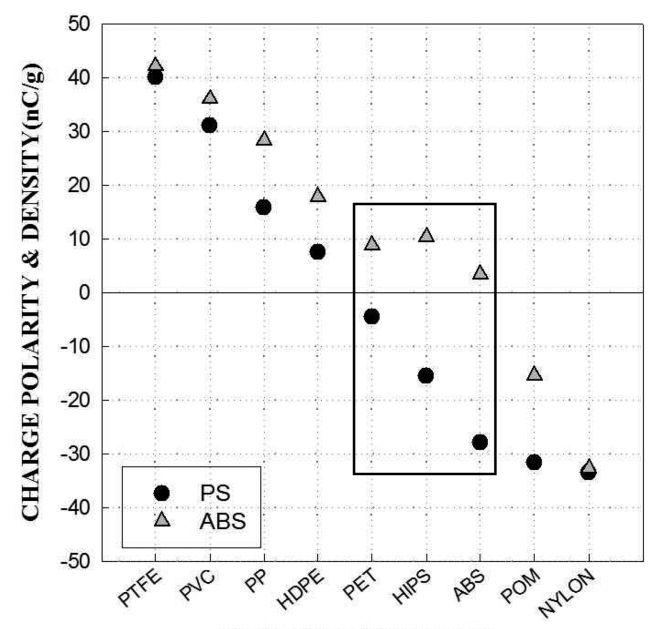

CHARGING MATERIALS

Fig. 4. Charging density of $\mathrm{ABS}$ and $\mathrm{PS}$ as various charging material.
물질들을 반대 극성으로 하전 시킬 수 있음을 확인하 였다.

최적의 하전물질 선정을 위해, 하전물질에 따른 선 별효율을 확인하였으며, 그 결과를 Fig. 5에 나타내었 다. 하전물질은 $\mathrm{ABS}$ 와 PS 혼합 폐플라스틱을 반대 극성으로 하전시킬 수 있는 PET, HIPS, ABS와 이들 과의 비교를 위해 $\mathrm{PTFE}, \mathrm{HDPE}, \mathrm{PP}$ 의 하전물질을 적용하였다. Fig. 5는 $\mathrm{ABS}$ 와 $\mathrm{PS}$ 의 비가 $1: 1$ 인 혼합 폐플라스틱을 이용하여 하전물질에 따른 $\mathrm{ABS}$ 의 품위 와 회수율을 나타낸 것이다. 동일한 극성으로 하전이 된 $\mathrm{PTFE}, \mathrm{HDPE}$ 그리고 $\mathrm{PP}$ 의 경우에는 회수율은 높 으나, 품위가 $60 \%$ 이하로 낮게 나타나는데, 혼합 폐 플라스틱의 혼합비가 $1: 1$ 인 점을 고려하였을 때, 선 별이 거의 이루어지지 않았음을 알 수 있다. 반면, $\mathrm{PET}, \mathrm{HIPS}$ 그리고 $\mathrm{ABS}$ 의 경우에는 $90 \%$ 이상의 회 수율과 $80 \%$ 이상의 품위를 관찰할 수 있는데, 그 중 에서도 하전특성연구에서 하전량의 차이가 크게 나타 난 $\mathrm{ABS}$ 의 경우는 품위와 회수율이 각각 $99.5 \%$, $92.5 \%$ 로 가장 높은 선별효율을 보여주었다. 따라서 본 연구에서는 $\mathrm{ABS}$ 를 하전물질로 선정하여 분리특성 연 구를 수행하였다.

\section{2. 전압세기의 영향}

Fig. 6은 하전시간 $30 \mathrm{sec}$., 분리대의 위치 positive electrode 방향으로 $2 \mathrm{~cm}$ 그리고 상대습도 $30 \%$ 에서 전 극의 전압세기를 $5 \mathrm{kV}$ 에서 $25 \mathrm{kV}$ 까지 변화하며, 전극의

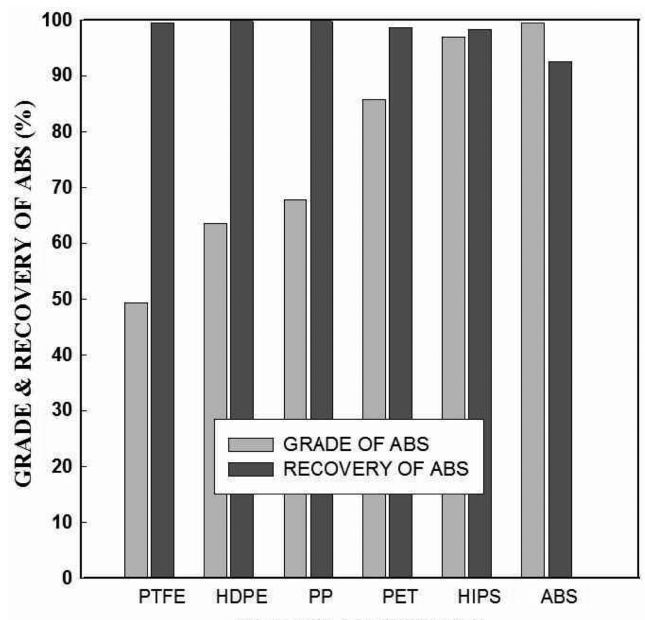

CHARGE MATERIALS

Fig. 5. Effect of charge material on grade and recovery of ABS material. 


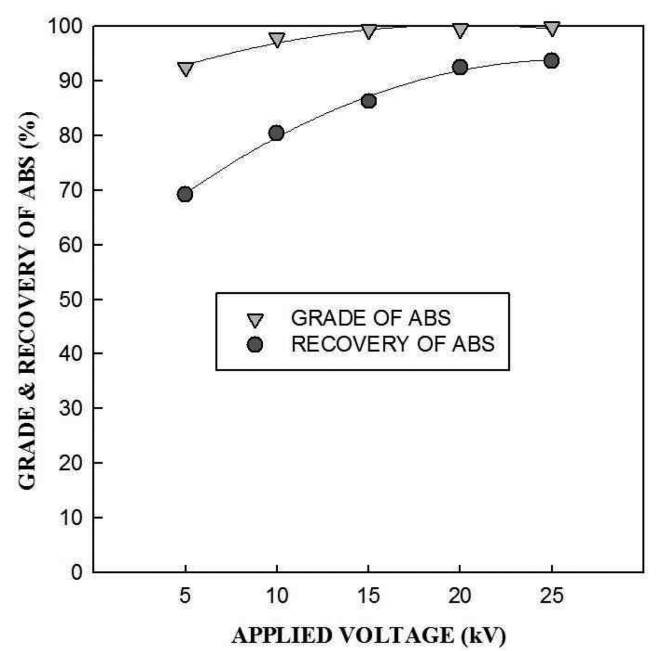

Fig. 6. Effect of applied potential on grade and recovery of ABS material.

전압세기가 $\mathrm{ABS}$ 와 PS 혼합플라스틱의 품위와 회수율 선별효율에 미치는 영향을 관찰한 것이다. 전압의 세기 가 커질수록 $\mathrm{ABS}$ 의 품위와 회수율이 증가하며, 높은 선별 효율을 나타낸다. 전압의 세기가 낮은 $5 \mathrm{kV}$ 에서는 품위와 회수율이 각각 $92.5 \%$ 와 $69.3 \%$ 로 가장 낮지만 전압세기가 증가할수록 품위와 회수율이 증가하여 $20 \mathrm{kV}$ 에서는 $99.5 \%$ 와 $92.5 \%$ 까지 증가하였다. 본 연구 에서의 최고 전압인 $25 \mathrm{kV}$ 에서는 품위와 회수율이 각 각 $99.9 \%$ 와 $93.75 \%$ 로 가장 높게 나타났지만 $20 \mathrm{kV}$ 에 서의 값과 큰 차이를 보이지 않으며 비슷한 선별 효율 을 보여주었다. 따라서 에너지효율 및 선별효율을 고려 하였을 때, 전압의 세기 $20 \mathrm{kV}$ 가 $\mathrm{ABS}$ 와 PS 혼합플라 스틱에서 $\mathrm{ABS}$ 를 회수하는데 효과적임을 알 수 있었다. 이와 같이 전극의 전압세기가 커질수록 선별효율이 증 가하는 이유는 하전된 입자들의 하전량이 $\mathrm{nC} / \mathrm{g}$ 단위로 매우 약하게 하전되어, 이를 분리하기 위해서는 높은 전 기 에너지가 필요하기 때문이다.

\section{3. 분리대 위치의 영향}

시료의 하전량은 입자의 일함수값, 온도 그리고 하전 시간 등의 인자들에 의해 영향을 받는다. 이로 인해 하 전된 입자들의 각각의 하전량이 다르기 때문에, 전기장 내에서 분리 될 때 전극으로 이동하는 속도와 거리가 다르다. 따라서 전기장 내 양극과 음극사이에 있는 분 리대의 위치를 이동시켜, 높은 선별효율을 보여주는 적 합한 조건을 얻을 수 있다.

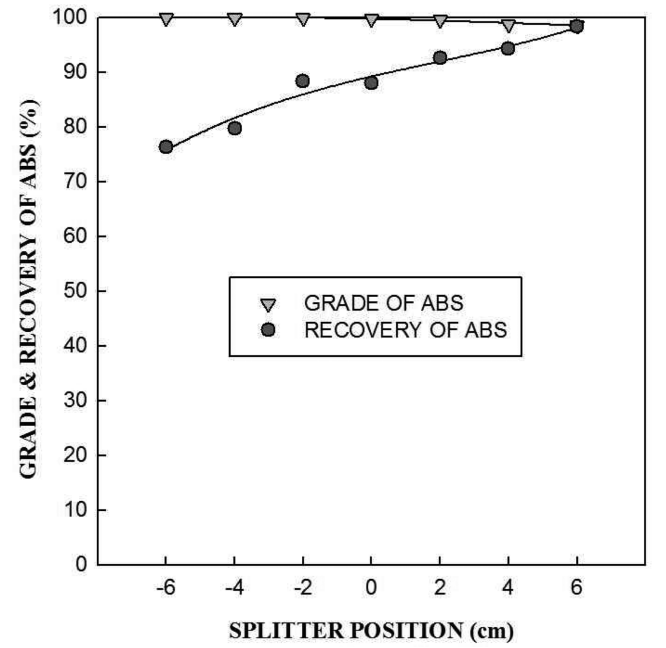

Fig. 7. Effect of splitter position on grade and recovery of ABS material.

Fig. 7은 분리대의 위치가 선별효율에 미치는 영항을 관찰하기 위하여 전압세기 $20 \mathrm{kV}$, 상대습도 $30 \%$, 하전 시간 $30 \mathrm{sec}$ 로 고정하고, 분리대의 위치를 양극과 음극 방향으로 각각 $6 \mathrm{~cm}$ 까지 $2 \mathrm{~cm}$ 씩 변화하며 실험을 수행 하였다. 분리대의 위치가 전기장의 양 전극에서 음 전 극으로 이동함에 따라, $\mathrm{ABS}$ 품위는 음 전극 $6 \mathrm{~cm}$ 지 점에서 $99.9 \%$, 양 전극 $2 \mathrm{~cm}$ 와 $6 \mathrm{~cm}$ 지점에서 각각 $99.5 \%, 98.2 \%$ 로 큰 차이를 보이지 않지만, 회수율은 각 지점에서 $76.2 \%, 92.5 \%$ 그리고 $98.2 \%$ 로 증가하는 것을 알 수 있다.

이와 같은 이유는 입자의 하전량 차이와 분리대 위치 에 따라 $\mathrm{ABS}$ 와 PS의 회수량이 달라지기 때문이다. 상대 적으로 하전효율이 높은 $\mathrm{PS}$ 의 경우, $\mathrm{PS}$ 의 회수가 분리대 위치변화에 거의 영향을 받지 않으나, $\mathrm{ABS}$ 는 분리대의 위치가 양 전극에서 음 전극으로 이동할수록 양극으로 하 전된 $\mathrm{ABS}$ 의 회수존이 넓어져 회수율이 증가하는 것이 다. 따라서 품위와 회수율을 고려할 때 양 전극 $2 \mathrm{~cm}$ 지 점에서 가장 효과적이었으며, 이 때 품위화 회수율은 각 각 $99.5 \%$, 회수율 $92.5 \%$ 인 결과를 얻었다.

\section{4. 하전시간의 영향}

Fig. 8은 하전시간이 선별효율에 미치는 영향을 관 찰하기 위하여 전압세기 $20 \mathrm{kV}$, 상대습도 $30 \%$, 분리 대의 위치 양극방향 $2 \mathrm{~cm}$ 로 고정하고, 하전시간을 10 초에서 60 초까지 증가시키며 실험하였다. 실험결과 하 전시간 30 초까지는 $\mathrm{ABS}$ 의 품위와 회수율이 증가하는 


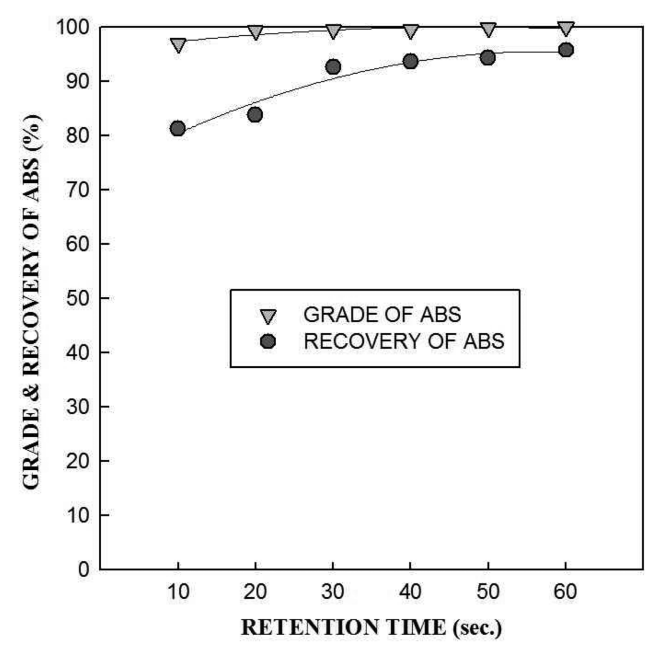

Fig. 8. Effect of retention time on grade and recovery of ABS material.

것을 알 수 있지만, 이보다 하전시간이 길어지면 선별 효율에 변화가 거의 없어 임계 시간에 도달됨을 알 수 있다.

이와 같이 하전시간이 길어질수록 선별효율이 증가하 는 이유는 하전시간이 길어짐에 따라 하전물질 내에서 입자간 또는 하전물질과 입자사이의 마찰 - 충돌의 빈 도수가 증가함에 따라, 효율적인 하전이 이루어져 하전 량이 증가하게 되기 때문이다. 반면 하전시간이 30 초 이상이 되면 선별효율에 큰 변화가 없는데, 이는 하전 시간 30 초가 대상 시료의 선별을 위하여 충분한 하전 을 제공하는 임계점으로 작용하였기 때문이다. 따라서 본 연구에서는 하전시간 30 초를 최적실험 조건으로 분 리실험을 수행하였으며, 이때 $\mathrm{ABS}$ 의 품위와 회수율이 각각 $99.5 \%$ 와 $92.5 \%$ 인 결과를 얻었다.

\section{5. 혼합비율의 영향}

본 실험에서 사용된 시료는 폐가전제품으로부터 PS 와 $\mathrm{ABS}$ 재질의 폐플라스틱을 각각 재질별로 회수한 것 으로, 최적의 선별효율을 보여주는 혼합비율을 관찰하기 위하여 $\mathrm{ABS}$ 와 $\mathrm{PS}$ 의 혼합비율을 각각 $1: 9,3: 7,5: 5$, $7: 3$ 으로 변화시키며 실험을 수행하였다. 실험변수인 전압 세기 $20 \mathrm{kV}$, 상대습도 $30 \%$, 분리대의 위치 양극방향 $2 \mathrm{~cm}$ 그리고 하전시간은 30 초로 고정하였다.

Fig. 9는 혼합 폐플라스틱의 비율에 따른 선별효율은 나타낸 것으로, $\mathrm{ABS}$ 의 양이 증가할수록 회수율은 감소 하나 품위는 증가하는 것을 볼 수 있다. $\mathrm{ABS}$ 와 $\mathrm{PS}$ 의

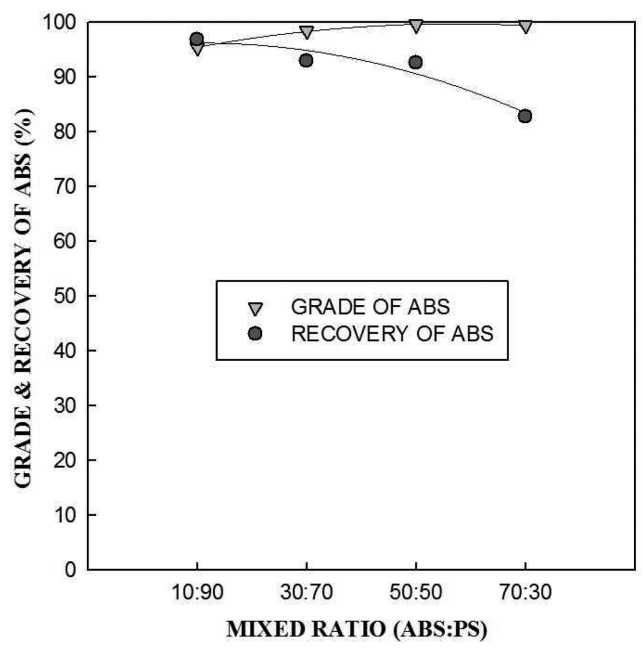

Fig. 9. Effect of mixed ratio on grade and recovery of ABS material.

비율이 $1: 9$ 일 때. 품위와 회수율이 각각 $95.4 \%, 96.8 \%$ 이지만, $\mathrm{ABS}$ 의 양이 증가하여 비율이 $5: 5$ 에서는 각각 $99.5 \%, 92.5 \%, 7: 3$ 일 때에는 각각 $99.4 \%, 82.8 \%$ 로 품위는 증가하지만, 회수율은 감소하게 된다. 이와 같이 $\mathrm{ABS}$ 의 양이 증가할수록 품위가 높아지는 이유는 비율 이 $1: 9$ 인 경우 상대적으로 양이 많은 PS 간의 마찰 충돌이 주를 이루어 혼합 폐플라스틱의 하전이 잘 이루 어지지 않았지만, $\mathrm{ABS}$ 의 양이 증가할수록 대상시료 간 의 마찰 - 충돌의 기회가 많아지면서 하전이 효율적으 로 이루어졌기 때문이다. 반면 회수율의 경우에는 $\mathrm{ABS}$ 의 양이 증가할수록 감소하는 경향을 볼 수 있는데, 이 는 앞서 언급한 바와 같이 $\mathrm{ABS}$ 의 양이 많아지면 $\mathrm{ABS}$ 간의 마찰- 충돌이 주를 이루어 하전효율이 떨어 지기 때문이다. 하전효율이 감소하면, 하전이 이루어지 지 않거나 약하게 하전된 입자들은 $\mathrm{ABS}$ 회수존까지 이동하지 못하여 PS의 회수존으로 배출되고, 이로 인해 $\mathrm{ABS}$ 의 회수율이 감소하게 된다. 따라서 혼합폐플라스 틱에서 $\mathrm{ABS}$ 의 품위와 회수율을 고려하였을 때, 품위와 회수율이 각각 $99.5 \%, 92.5 \%$ 를 보여주는 $\mathrm{ABS}$ 와 $\mathrm{PS}$ 의 비율 $5: 5$ 에서 가장 높은 선별효율을 확인하였다.

\section{6. 상대습도의 영향}

Fig. 10은 상대습도가 혼합 폐플라스틱의 재질분리에 서 선별효율에 미치는 영향을 나타낸 것이다. 공급전압 세기 $20 \mathrm{kV}$, 분리대의 위치 양극방향 $2 \mathrm{~cm}$ 그리고 하 전시간은 30 초 조건하에서, 상대습도를 $20 \sim 70 \%$ 까지 변 


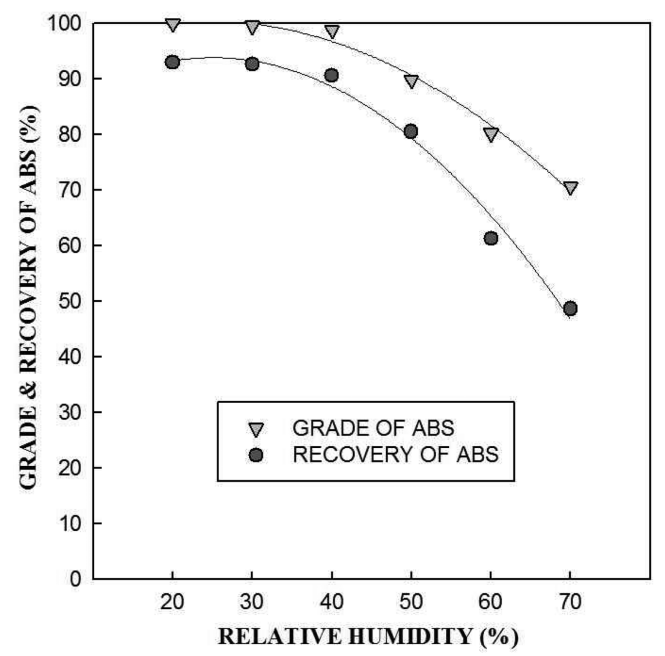

Fig. 10. Effect of relative humidity on grade and recovery of ABS material.

화하며 혼합 폐플라스틱에서 $\mathrm{ABS}$ 를 회수를 위한 선별 효율을 관찰하였다. 실험결과 상대습도 $40 \%$ 까지는 $\mathrm{ABS}$ 의 품위와 회수율에 큰 영향을 미치지 않았지만, 이보다 상대습도가 증가하면 $\mathrm{ABS}$ 의 품위와 회수율이 크게 감소되는 것을 알 수 있다.

상대습도가 가장 낮은 $20 \%$ 일 때, $\mathrm{ABS}$ 의 품위와 회 수율이 각각 $99.9 \%$ 와 $92.9 \%$ 로 가장 높고, 상대습도가 $40 \%$ 까지 증가하여도 각각 $98.7 \%$ 와 $90.1 \%$ 로 큰 차이 를 보이지는 않는다. 그러나 상대습도가 $40 \%$ 이상이 되면 선별효율이 크게 저하되어, 상대습도가 최고인 $70 \%$ 일 때에는 품위와 회수율이 각각 $70.6 \%$ 와 $48.6 \%$ 까지 감소하는 것을 알 수 있다. 따라서 선별효율을 높 이기 위해서는 상대습도가 $40 \%$ 이하로 유지되어야 함을 알 수 있으며, 본 연구에서는 상대습도 $30 \%$ 를 최적조 건으로 재질분리실험을 수행하였으며, 이때의 $\mathrm{ABS}$ 의 품 위와 회수율이 각각 $99.5 \%$ 와 $92.5 \%$ 인 결과를 얻었다. 이처럼 상대습도가 $\mathrm{ABS}$ 와 PS 혼합 폐플라스틱의 재질 분리에 영향을 미치는 이유는, 상대습도가 높을수록 공 기 중의 수분이 마찰하전시의 입자 간의 표면분극을 방 해하고, 입자들이 하전이 되더라도 입자의 전하를 방전 시켜 하전량을 감소시키기 때문이다.

\section{5. 결 론}

본 연구에서는 마찰하전형정전선별법을 적용하여, 폐 가전제품으로부터 회수된 $\mathrm{ABS}$ 와 PS 혼합폐플라스틱의
재질분리에 적합한 하전물질의 결정 및 하전특성을 연 구하고, 하전효율 및 분리효율을 극대화할 수 있는 최 적 선별조건을 규명하고자 하였으며, 다음과 같은 결론 을 얻었다.

1. $\mathrm{ABS}$ 와 $\mathrm{PS}$ 의 혼합 폐플라스틱의 효율적인 하전 및 선별을 위한 하전특성실험 결과, PET, HIPS 그리고 $\mathrm{ABS}$ 가 $\mathrm{ABS}$ 와 $\mathrm{PS}$ 를 반대 극성으로 하전시킬 수 있음 을 확인하였으며, 이들 물질 중 $\mathrm{ABS}$ 가 가장 높은 선 별효과를 나타냈다.

2. 시료의 하전시간과 혼합비율에 따른 선별효율을 관 찰한 실험결과, 하전통내에서 30 초까지는 선별효율이 증 가하지만, 이보다 길어지면 선별효율에 변화가 거의 없 어, 대상시료를 충분히 하전시킬 수 있는 임계 하전시 간임을 알 수 있었다. 혼합비율의 경우 $\mathrm{ABS}$ 와 $\mathrm{PS}$ 의 혼합비율이 10:90에서 50:50으로 $\mathrm{ABS}$ 시료양이 증가할 수록 하전물질 및 혼합시료간의 충돌 및 마찰이 증가하 여 선별효율이 증가하나, 이보다 양이 많아져 70:30이 되면 $\mathrm{ABS}$ 단일시료의 충돌이 주를 이루어 효율이 감소 하였다.

3. $\mathrm{ABS}$ 와 $\mathrm{PS}$ 혼합 폐플라스틱에서 $\mathrm{ABS}$ 회수를 위해 $\mathrm{ABS}$ 재질의 하전물질을 이용하여 분리실험을 수행한 결과, 공급전압세기 $20 \mathrm{kV}$, 분리대의 위치 양극방향 $2 \mathrm{~cm}$, 상대습도 $30 \%$ 그리고 하전시간은 30 초인 실험조 건에서 $\mathrm{ABS}$ 의 품위와 회수율이 각각 $99.5 \%$ 와 $92.5 \%$ 인 결과를 얻었다.

\section{감사의 글}

본 논문은 환경부의 글로벌탑 환경기술개발사업 중 폐금속유용자원재활용기술개발사업단의 지원에 의하여 연구되었으며 이에 감사드립니다(GT-11-C-01-170-0).

\section{참고문헌}

1. Ho-Seok Jeon et al., 2006: The Development of Electrostatic Separation Technique for Recycling of Life Circles Waste Plastic, J. of Korean Inst. of Resources Recycling, 15(1), pp.28-36.

2. Sung-kyu Lee et al., 2010: Recycling and development of environmental-friendly production system for plastic waste, Journal of disaster prevention, 12(2), pp.110-120, National institute for disaster prevention, Seoul, Korea.

3. Ho-Seok Jeon et al., 2010: Development of Electrostatic Separation Technique for Recovery of Soft PVC from 
Medical Plastic Waste, J. of Korea Society of Waste Management, 27(2), pp.159-164.

4. Hong-Jun Choi, Sang Mun Jeong and Bong-Hee Lee, 2011: Study on the Liquefaction Characteristics of ABS Resin in a Low-Temperature Pyrolysis, Korean Chem. Eng. Res., 49(4), pp.417-422.

5. Ho-Seok Jeon et al., 2006: The Development of Triboelectrostatic Separation Technique for Recycling of Seaweed Drying Waste Plastic, J. of Korea Society for Geosystem Engineering, 43(6), pp.579-584.

6. Ho-Seok Jeon et al., 2007: A Study on Material Separation of Heavy Geoup Plastics be Triboelectrostatic Separation, J. of Korean Inst. of Resources Recycling, 16(2), pp56-62.

7. Sang-Ho Baek et al, 2008: Development of Electrostatic Separation Technique for Removal of PBT from Waste ABS-PBT Mixture, J. of Korea Society for Geosystem Engineering, 45(3), pp.249-256.
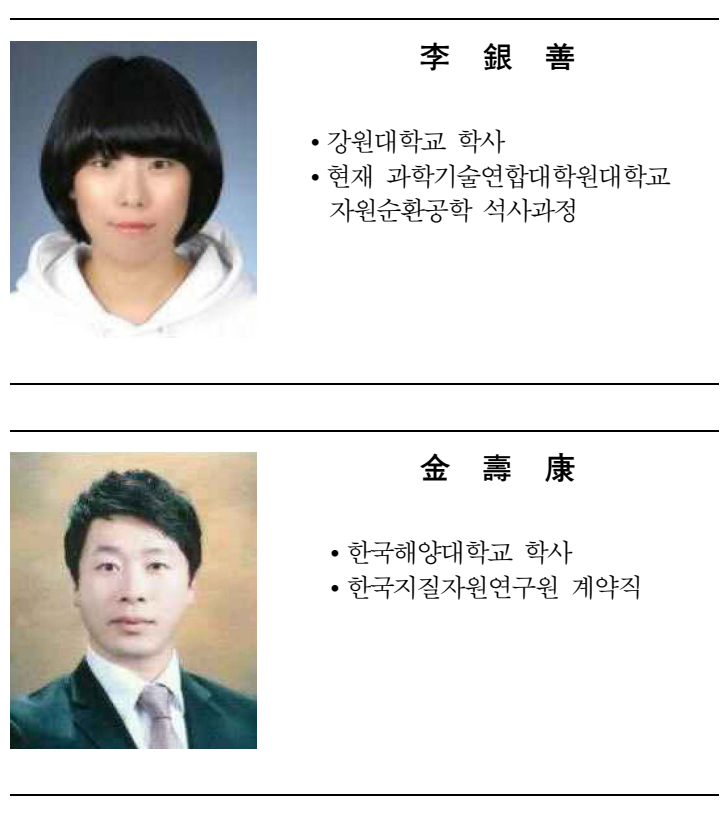

陳 鎬 逸

- 서울대학교 대학원 자원공학과 공학박사

- 현재 강원지역사업평가원 지역사업평가단 단장

J. of Korean Inst. Resources Recycling Vol. 22, No. 6, 2013
8. Gjergj Dodbiba, Atsushi Shibayama, Toshio Miyazaki and Toyohisa Fujita, 2003: Triboelect-roststic Separation of ABS, PS and PP Plastic Mixture, 44(1), pp.161-166.

9. Chul-Hyun Park et al, Ho Seok Jeon and Jai Koo Park, 2006: A Study on Charging Properties and Triboelectric Series of Plastic by Tribo-charging, J. of Korea Society for Geosystem Engineering, 43(6), pp.560-569.

10. Kelly, E. G. and sottiswood, D. J., 1989: The theory of electrostatic separation : a Rewiew Prat I, Fundamentals, Mineral Engineering, 2(1), pp.33-46.

11. Mihai Lungu, 2004 : Electrical separation of plastic materials using the tricoelectric effect, Minerals Engineering, 17(1), pp66-75.

12. Korea Ptrolchemical Industry Association, 2013, 2013 Petrolchemical minibook: http: //www.kpia.or.kr/file/ 2013_minibook.pdf.

13. Statistics Korea, 2013: http://www.index.go.kr, July 04, 2013.

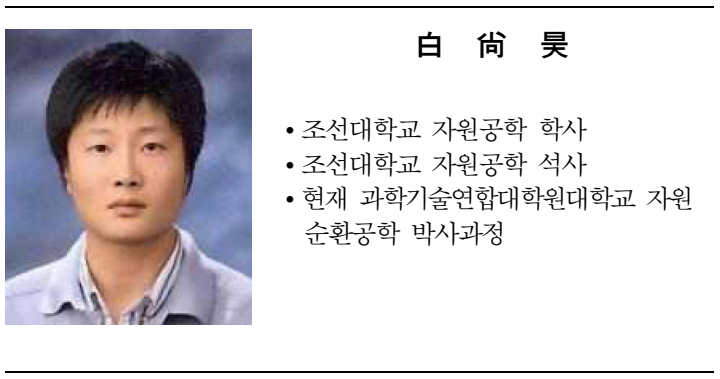

崔 佑 鎭

- 현재 수원대학교 환경공학과 교수

- 당 학회지 제 9 권 1 호 참조

\section{全 好 錫}

- 현재 한국지질자원연구원 광물자원연구본부 책임연구원 - 당 학회지 제 10 권 3 호 참조 